\title{
Pure Prostatic Leiomyoma: A Case Report
}

\author{
Prostatın Pür Leiomyomu: Olgu Sunumu
}

\author{
Jamal Musayev ', Asif Jahangirov ${ }^{2}$, Adalat Hasanov ', Mahmud Baghirzade ${ }^{1}$ \\ 1 Azerbaijan Faculty of Medicine, Department of Pathology, Baku, Azerbaijan \\ 2 Merkezi Neftçiler Hospital, Department of Urology, Baku, Azerbaijan
}

Gelis tarihi (Submitted): 2020-01-18 Kabul tarihi (Accepted): 2020-05-04

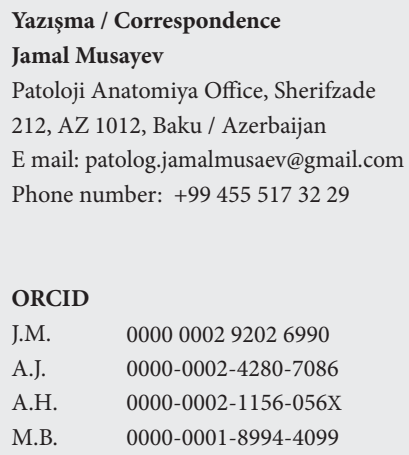

\section{ORCID}

J.M. $\quad 0000000292026990$

A.J. $\quad 0000-0002-4280-7086$

A.H. $\quad 0000-0002-1156-056 \mathrm{X}$

M.B. 0000-0001-8994-4099

\section{(c) (P) 8}

This work is licensed under a Creative Commons Attribution-NonCommercial 4.0 International License.

\section{Özet}

Leiomyomlar benign mezenşimal düz kas tümörleridir. Prostatın pür leiomyomları nadirdir. Burada kliniğe infravezikal obstrüksiyon semptomları ile başvuran 77 yaşında olgu sunulmuştur. Rektal tuşe ve ultrasonografik inceleme ile prostatda büyüme belirlendi. Açı prostatektomi uyguland. Makroskopik incelemede prostat 172 gr ağırlıktaydı ve kesit yüzeyinde solid nodüler lezyon görüldü. Mikroskopik incelemede lezyon nükleer atipi, nekroz ve mitotik aktivite içermeyen iysi hücre proliferasyonundan oluşuyordu. Radyolojik yöntemler bu ve benzer lezyonların biyolojik doğasını belirlemek için yeterli değildir. $\mathrm{Bu}$ açıdan histopatolojik inceleme malignitelerin ekarte edilmesi için önemlidir. Açık prostatektominin uygulanması hem tanısal, hem de tedavi açısından efektifdir.

Anahtar Kelimeler: Prostat, mezenşimal tümör, iysi hücre proliferasyonu, nodül.

\section{Abstract}

Leiomyomas are benign mesenchymal smooth muscle tumours. Pure leiomyoma of prostate is very rare. Here we presented a case of 77 -year-old men who admitted to hospital with symptoms of infravesical obstruction. The per-rectal and ultrasonographic examination revealed an enlarged prostate. Open prostatectomy procedure was performed. The prostate weigh was $172 \mathrm{gr}$ in gross pathological examination and solid nodular lesion was observed on the cut surface of the prostate. Microscopically, the lesion was composed of spindle cell proliferation, without nuclear atypia, necrosis and mitotic activity. Radiological methods are inadequate for determination of the biological nature of such nodules. Therefore, histopathology is very important for excluding of malignancy. Open prostatectomy is an effective method for both treatment and diagnostic purposes.

Keywords: Prostate, mesenchymal tumour, spindle cell proliferation, nodule.

This article presented as poster on 29th European Pathology Congress in Amsterdam at September 2017. Bu olgu 2-6 Eylül 2017 tarihlerinde, Amsterdam/Hollanda' da gerçekleșen 29. Avrupa Patoloji Kongresinde poster olarak sunulmuştur. 


\section{GiRiş}

Prostatın gerçek mezenşimal tümörleri çok ender olup bu bölgede gelişen tümörlerin \%1'den azını oluşturmaktadır. Nadir rastlandığı için hem klinik, hem radyolojik, hem de patolojik açıdan tanısal zorluk oluşturmaktadır. Özellikle küçük kor biyopsilerinde benign mezenşimal tümörlerin olağan prostat stromasından ayırt edilmesi çoğunlukla imkansızdır. Bir çok doktorun bu konuda sinırlı tecrübeye sahip olması da bu tümörlerin gözden kaçmasına ve erken tanı alamamasına neden olan bir diğer faktördür (1). Prostatın stromal lezyonları mezenşimal tümörlerinin önemli bir kısmını oluşturmaktadır. Bununla birlikte düz kas dokusundan gelişen tümörler prostat için nadirdir. Burada bir prostat leiomyomu olgusu nadir olması ve tanısal zorluk oluşturması nedeni ile sunulmuştur.

\section{OLGU SUNUMU}

İnfravezkal obstrüksiyon şikayeti ile üroloji polikliniğine başvuran 77 yaşında hastada rektal tuşede prostatın sert-elastik, yüzeyinin düzgün olduğu belirlendi. Transrektal ultrasonografik (TRUS) incelemede prostatın yaklaşık 200 gr ağırlıkta olduğu ve diffüz büyüme gösterdiği belirlendi. Serum prostat spesifik antijen (PSA) düzeyi 2,57 ng/dl idi. Prostatın boyutu gözönüne alınarak hastaya açı prostatektomi uygulandı. Makroskopik incelemede prostat 172 gr ağırlıktaydı ve yapılan kesitlerde 50x60×60 mm ölçülerinde, kirli beyaz renkli, elastik, düzgün sınırl, solid nodüler lezyon görüldü (Şekil 1). Mikroskopik incelemede lezyon bir birini çaprazlayan iysi hücre demetlerinden oluşuyordu ve belirgin fibröz kapsül ile çevrelenmişti. İysi hücrelerde atipi, mitotik aktivite ve nekroz görülmedi. Tamamı örneklenen nodüler lezyonda prostata ait asiner ve duktal yapı bulunamadı (Şekil 2). İmmünhistokimyasal (İHK) incelemede iysi hücrelerde düz kas aktini (SMA) ile diffüz sitoplazmik boyanma elde edilirken, Ki67 ile hücrelerin \%1'inde nuklear boyanma izlendi (Şekil 3). Nodül dışı prostat dokusunda fokal hiperplazi alanları dışında herhangi bir özellik yoktu. Belirtilen bulgulara dayanarak tanı prostat leiomyomu olarak rapor edildi. Yirmi dört aylık takipte hastada yineleme ve komplikasyon saptanmadi.

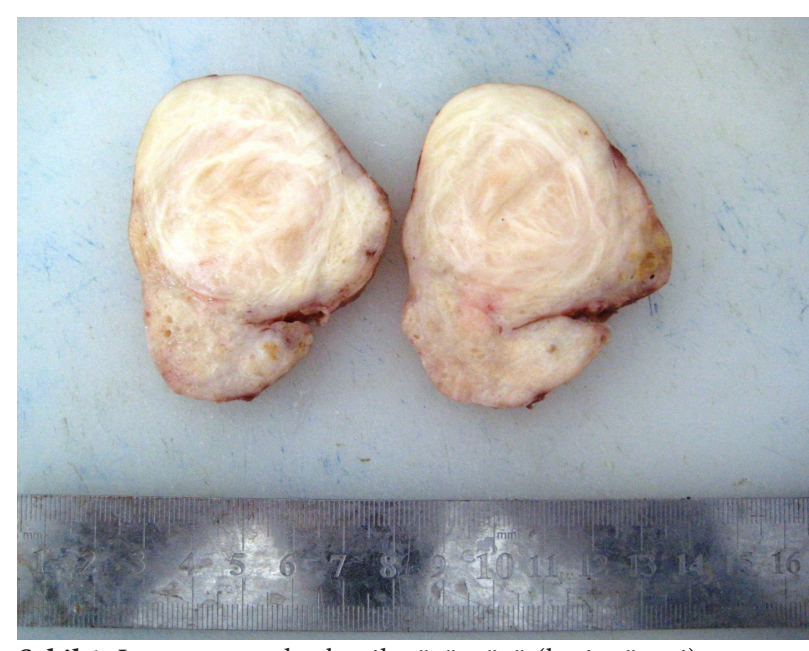

Şekil 1. Lezyonun makoskopik görüntüsü (kesit yüzeyi).

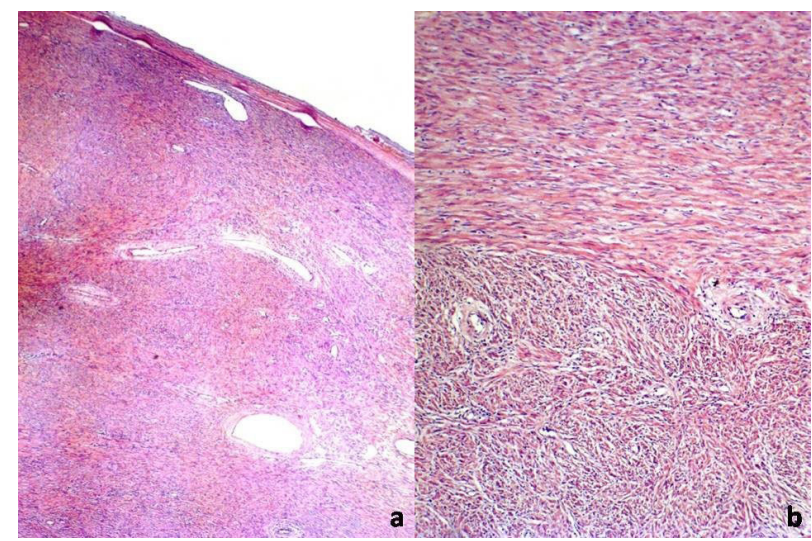

Şekil 2. Tümörü çevreleyen fibröz kapsül (a: HE×100) ve iysi hücre demetlerinden oluşan tümör dokusu (b: HE×400) .

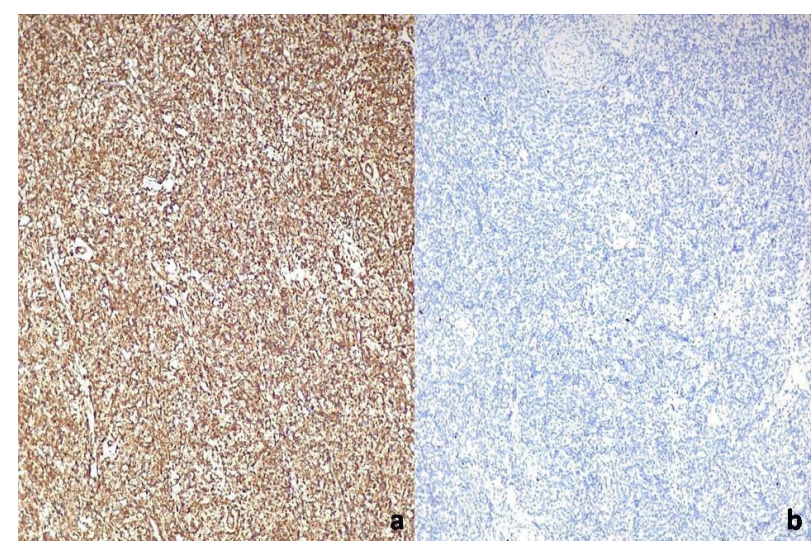

Şekil 3. İysi hücrelerde SMA pozitifliği (a) ve Ki67 oranı (b). 


\section{TARTIŞMA}

Leiomyomlar düz kas hücresi kökenli benign tümörler olup çoğunlukla miyometriumdan gelişirler. Erkek genital organlarında nadiren görülürler. Prostat lokalizasyonlu yaklaşık 100 olgu rapor edilmiştir (2).

Prostat leiomyomları genellikle 48 yaşın üzerinde görülürler; daha genç yaşta ve geriatrik yaş grubunda ise daha seyrektirler $(3,4)$. Nokturi ve dizüri en sık görülen klinik bulgulardır. Serum PSA düzeyi bu olgularda genellikle normaldir; leiomyoma eşlik eden adenokarsinom veya seminal vezikül lokalizasyonlu leiomyom olgularında ise yüksek serum PSA düzeyi gözlemlenebilir $(5,6)$. Olgumuzun yaşı 77 idi ve infravezikal obstrüksiyon semptomları ile kliniğe başvurmuştu; serum PSA düzeyi normaldi.

Prostat lezyonlarının tanı sürecinde önemli bir yere sahip olan TRUS ile leiomyomların yakalanması her zaman mümkün değildir. Olguların bir kısmında diffüz prostat hiperplazisi görüldüğü halde bazılarında prostatta asimetriye neden olan, kuşkulu nodüler lezyon yakalanmaktadır $(3,4,7)$. BT ile lezyonun ölçüleri ve sınırları daha net görülmektedir (8). Manyetik rezonans görüntülemede T2 ağırlıklı sekanslarda kitle içinde düşük sinyal intensitesi görülmekte ve lezyonlar genellikle Likert 4-5 lezyon olarak değerlendirilmekte$\operatorname{dir}(2)$.

Mikroskopik olarak prostat leiomyomu iysi hücre demetlerinden oluşan, düzgün sınırları ve kapsülü olan, içinde her hangi bir asiner ve duktal yapı içermeyen, benign tümör olarak tanımlanmaktadır. Tümörün bu özellikleri prostatektomi spesmenlerinde daha belirgin görüldüğü halde, kalın iğne biyopsisi ve transüretral rezeksiyon (TUR) gibi küçük doku parçalarından oluşan spesmenlerde ayırt edilmesi zordur. Kalın iğne biyopsisi uygulanan prostat leiomyomu olgularında düşük dereceli malignitelerin ekarte edilmesinde zorluk yaşandığı, böylece hastaya radikal prostatektomi ve bölgesel lenf nodu disseksiyonu gibi geniş çaplı cerrahi işlemlerin uygulanabildiği rapor edilmiştir (7). Prostat adenokarsinomu ve leiomyomuna eş zamanlı rastlanılması mümkündür (6). Bu nedenle prostat leiomyomu olgularında leiomyom dışı prostat dokusunun dikkatlice incelenmesi gerekmektedir.

İmmünhistokimyasal (İHK) incelemede leiomyomlar için bilinen genel özellikler prostat yerleşimli leiomyomlar için de geçerlidir. SMA ile diffüz sitoplazmik boyanma ve düşük Ki67 oranı esas karakteristik bulgulardir.

Prostat leiomyomlarının ayırıcı tanısinda gastrointestinal stromal tümör (GİST), leiomyosarkom, stromal (fibromuskuler) hiperplazi gibi iysi hücre proliferasyonu gösteren lezyonlar göz önünde bulundurulmalıdır. GİST' e prostatta ender rastlanmaktadır ve rekürrens ihtimali bulunmaktadır. İHK incelemede CD34 ve CD117 pozitifliği ile leiomyomdan ayırt edilebilir (9). Düz kas aktininin leiomyomlarda olduğu gibi GİST’ lerde de pozitif olması ayırıcı tanıda tuzak oluşturabilir. Stromal fibromuskuler hiperplazi, prostatta diffüz büyümeye neden olması ile leiomyomlardan farklı şekilde kendini göstermektedir ve TUR spesmenlerinde leiomyomdan ayırt edilmesi rutin yöntemlerle imkansızdır. Leiomyosarkomlar yüksek mitotik aktivitesi ve Ki67 oranı ile leiomyomlardan ayırt edilmektedir. Bunun yanısıra atipi ve nekroz ayırıcı tanı için yardımcı bulgulardır. Bu bakımdan nekroz ve önemli ölçüde atipi içermediği için düşük dereceli leiomyosarkomların leiomyomlardan ayırt edilmesi daha zordur. Ayrıca garip çekirdekler içeren ve mitotik aktivite gösteren atipik leiomyomlar da leiomyosarkoma benzerliği ile tanısal zorluk oluşturmaktadır (10).

\section{SONUÇ}

Radyolojik yöntemler bu ve benzer lezyonların biyolojik doğasını belirlemek için yeterli değildir. Bu açıdan histopatolojik inceleme malignitelerin ekarte edilmesi için önemlidir. Açık prostatektomi hem tanısal, hem de tedavi açısından efektifdir.

\section{KAYNAKLAR}

1. McKenney JK. Mesenchymal tumors of the prostate. Mod Pathol 2018;31:S133-142.

2. Mussi TC, Costa YB, Obara MT, Queiroz MR, Garcia RG, Longo JA, Lemos GC, Baroni RH. Multiparametric 
magnetic resonance imaging findings of prostatic pure leiomyomas. Einstein Sao Paulo 2016;14:374-377.

3. Özekinci S, Em S. Prostat leiyomyomu; olgu sunumu. Dicle Tip Dergisi 2005;32:94-95.

4. van Ulden-Bleumink WM, Dom PG, Ramakers BP, van Adrichem NP. A rare prostatic diagnosis of an old man: a pure prostatic leiomyoma. Case Rep Urol 2013;741235.

5. Arnold SJ, Lin FC, Eldersveld JM, Phung MC, Walker JR, Nguyen TT. Seminal Vesicle Leiomyoma Mimicking Extra-prostatic Extension of Prostatic Adenocarcinoma. Urol Case Rep 2016;06:18-20.

6. Keske M, Canda AE, Atmaca AF, Bedir F, Gecit I, Ardicoglu A, Aydogdu OB, Agackiran Y, Ocal BG. A large posteriorly located prostatic mass lesion challenging the robotic surgeon: prostate leiomyoma. J Endourol Case Rep 2017;03:61-63.
7. Ringoir A, Rappe B, Dhaene K, Schallier D. Prostatic leiomyoma: a case report. Urol Case Rep 2016;09:45-47.

8. Imai S, Ayabe Y, Iiyama T, Muramatsu H, Matsuo Y, Kudo S. Leiomyoma of the prostate: CT and MR findings. Abdom Imaging 2002;27:674-676.

9. Etit D, Kar H, Ekinci N, Yenipazar AE, Çakalağaoğlu F. Extra-gastrointestinal stromal tümör of prostate. Balkan Med J 2017;34:168-171.

10. Rosen Y, Ambiavagar PC, Vulatin JC, et al. Atypical leiyomyoma of prostate. Urology 1980;15:183-185. 